\title{
Study Analysis for Development of Discovery Learning Model Based on Naturalist Intelligence to Improve Student Science Literation
}

\author{
Ari Suryawan ${ }^{1}$, Kun Hisnan Hajron ${ }^{2}$, Dhuta Sukmarani ${ }^{3}$, Tawil ${ }^{4}$ \\ \{ari.surya_88@ummgl.ac.id ${ }^{1}$ \} \\ Faculty of Teacher Training and Education Sciences, Universitas Muhammadiyah Magelang, 56172, \\ Indonesia ${ }^{1,2,3,4}$
}

\begin{abstract}
This study aims to analyze the needs of the Development of Discovery Learning Model Based on Naturalist Intelligence. The research was conducted using a survey method. The research subjects were 20 Elementary Schools, involving 20 teachers and 180 students. The focus of the assessment is the teacher's response to the development of the Discovery Learning model based on naturalist intelligence and student scientific literacy. Data were collected by interview, questionnaire, observation. Data were analyzed descriptively quantitative. The results of the analysis show that (1) the principal supports efforts to develop a learning model as a form of adaptation to learning changes due to the COVID-19 pandemic, (2) the teacher supports and states readiness to be involved in development, (4) the students' scientific literacy is categorized as lacking. The implication is the development of Naturalist Intelligence Based Discovery Learning to Improve Students Science Literacy.
\end{abstract}

Keywords: Discovery Learning Model, Naturalist, Literacy Science

\section{Introduction}

Science learning is a process of interaction between teachers and students in studying events that occur in nature, through scientific activities to achieve learning goals. A very important goal of learning science is to develop process skills and investigate the natural environment, solve problems, and make decisions. Because of the entire educational process in schools, the learning process is the main part of learning activities. In line with that, the essence of science learning is to emphasize the process, learning science as a product and as a scientific attitude.

Learning science as a scientific attitude is an attitude that is developed when students carry out a learning process such as experimental activities, discussions, or simulations. Learning science as a product is the knowledge that students get from the learning process they do. Meanwhile, science learning as a process is a process to obtain a product. The knowledge that students get from the teacher and also reading books, should be supported by student experiences during the learning process to gain this knowledge through discovery, investigation or discussion activities. Through this learning experience, students become more active and the knowledge gained lasts longer, has better understanding of the material being studied, and is able to use this knowledge in everyday life.

Teachers play an important role in the learning process, namely choosing a learning model that suits the needs of students and the material being taught, directing students during the 
learning process, and facilitating students when carrying out the learning process. By carrying out its role as best as possible, the teacher hopes that the learning process can run well so that it affects the increase in student learning outcomes. The opinion that all children are intelligent and that children have different ways of being smart is a basic proposition of the theory of multiple intelligence. The basic proposition of the theory of multiple intelligence must be understood and believed by every teacher. The teacher must know and believe that every child has intelligence and the teacher's job is to provide stimulation or different stimuli so that students have the opportunity to raise and develop every indicator of intelligence they have.

Produces an intellectual work entitled Intelligence Reframed which states that the human brain stores at least nine types of agreed intelligence, which consist of: linguistic intelligence, logic-mathematical intelligence, visual-spatial intelligence, intelligence kinesthetic, musical intelligence, interpersonal intelligence, intrapersonal intelligence, naturalist intelligence and existential intelligence [1]. Naturalist intelligence is one of the nine intelligences mentioned by Howard Gardner, Naturalist intelligence is the ability of a person to demonstrate proficiency in recognizing and classifying many species (flora and fauna) in their environment, recognizing the existence of a species, mapping the relationships between several species, including sensitivity to other natural phenomena (cloud formations, mountains), distinguishing inanimate objects and the ability to perceive forms and connecting elements in nature [2].

Discovery learning model is a learning model that is needed in carrying out the science learning process, because the meaning of discovery itself is discovery through experimentation which is part of the science process [3]. The discovery learning model is good because in the discovery students have the opportunity to be actively involved, so that it can increase student participation and learn more meaningful learning [4]. The application of discovery learning models is expected to increase learning outcomes.

The development of technology and information has influenced the development of the world of education in Indonesia. Along with advances in information technology, the development of education is increasingly changing and encouraging various efforts for better changes. The education process has shown rapid development in the fields of more advanced curriculum, learning methods, and supporting facilities. Overall, it can be said that the changes that occur are reforms in the education system to balance advances in science and technology globally. Education can also be a force to make changes so that conditions are better [5].

One of the parameters for the quality of education in a country is that it is reflected in the achievements of its students in participating in National and International studies. Scientific literacy is a person's ability to understand science, communicate science, and apply scientific knowledge to solve problems so that they have a high attitude and sensitivity to themselves and their environment in making decisions based on scientific considerations [6]. PISA (Program for International Student Assessment) is a literacy study conducted by the Organization for Economic Co-Operation and Development (OECD) and the Unesco Institute for Statistics. Thus, it is necessary to develop a learning model based on the nature of science learning, children's intelligence, and global demands [7].

\section{Method}

This research refers to the Plomp development model which includes: 1) the initial investigation phase; 2) the design / design phase; 3) realization / construction phase; 4) test, evaluation \& revision phase; and 5) implementation phase. The first phase, namely the initial 
investigation phase, is information gathering (need assessment) then designing and developing learning model products. The subjects of this study were students, teachers, school principals and students' initial scientific literacy level tests. Data were collected by means of observation, questionnaires and tests. Observations were made on the implementation of the learning process. The questionnaire was carried out in a limited manner with science teaching teachers in schools to determine the obstacles faced, especially in learning and the need for developing models according to student intelligence. The test method was carried out to trace the initial conditions of students' scientific literacy levels. Furthermore, the results of literature studies and field studies are used as materials for designing the development of learning models that are ready to be validated by experts.

\section{Results and Discussion}

\subsection{Level of teacher understanding of the research variables}

In this needs analysis, it has been distributed to 20 elementary school teachers. Based on the results of the questionnaire, it can be described that the majority of the teachers in the study sample have understood innovative learning models, discovery learning models, naturalist intelligence and scientific literacy. This is influenced by the implementation of the 2013 curriculum that has been implemented. The teacher's understanding of this aspect is because there are workshops that are carried out regularly and periodically monitoring by the principal. Therefore, $70 \%$ of teachers expressed their hopes for an effort to develop a student-centered learning model (SCL) and be immediately carried out because of the COVID-19 pandemic, they are required to make learning innovations that can be done at home and capacity student intelligence. Several teachers have tried to develop a learning model during the Covid 19 pandemic but the measure of success has not been measured in detail. This was done because we were looking for an effective formula for teaching during the Covid 19 pandemic to learn online. The following shows the results of the survey on teacher understanding of the research variables can be seen at Figure 1.

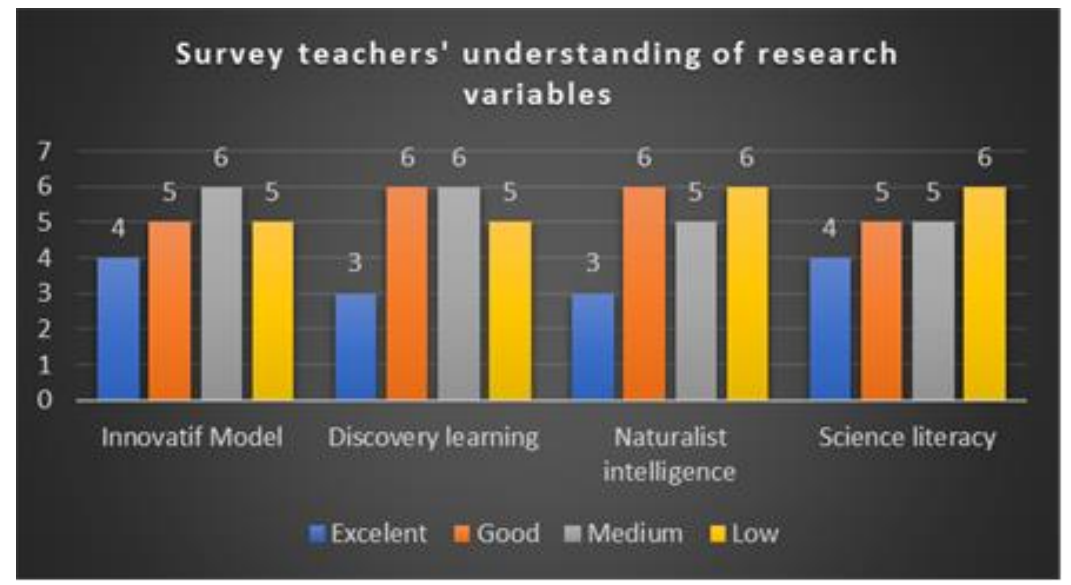

Fig. 1. Level of teacher understanding of the research variables 
The result of the next analysis is a questionnaire about the need for the development of learning models. The majority of teachers hope that there will be the development of a science learning model that can facilitate intelligence and can improve children's scientific literacy skills. Based on the results of adoption, it is found that there is optimism for the success of developing a learning model. Currently, children have entered the digital age, so learning must continue to be developed and based on 21 st century abilities in accordance with the characteristics of the 2013 curriculum that is currently being implemented in Indonesia [8]. The teacher respon to model development can be seen at Figure 2.

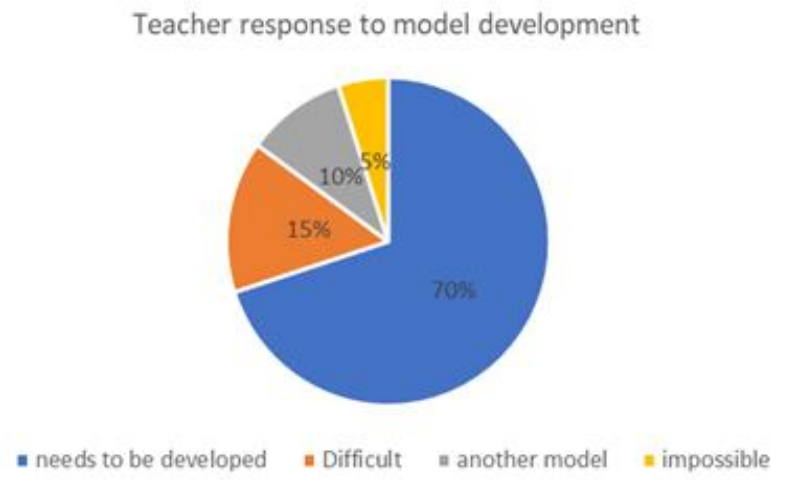

Fig. 2. Teacher response to model development

There are $70 \%$ agree that there is a model development because the current learning model is not optimal enough to achieve a high level of scientific literacy. $15 \%$ of teachers gave an opinion that there were difficulties in implementation due to the conditions of the Covid 19 pandemic which caused them to not be able to carry out learning in class. $10 \%$ of teachers think to use another model because discovery learning models have been widely used. The remaining $5 \%$ gave an opinion that it could not be done because of inadequate infrastructure.

\subsection{Level of scientific literacy}

Acquisition of research data related to scientific literacy skills in each aspect of knowledge and scientific competence is obtained by calculating the percentage of achievement of the test results for the aspects of knowledge and competence. The percentage of attainment of scientific literacy skills per indicator in the aspect of knowledge is presented in Figure 3.

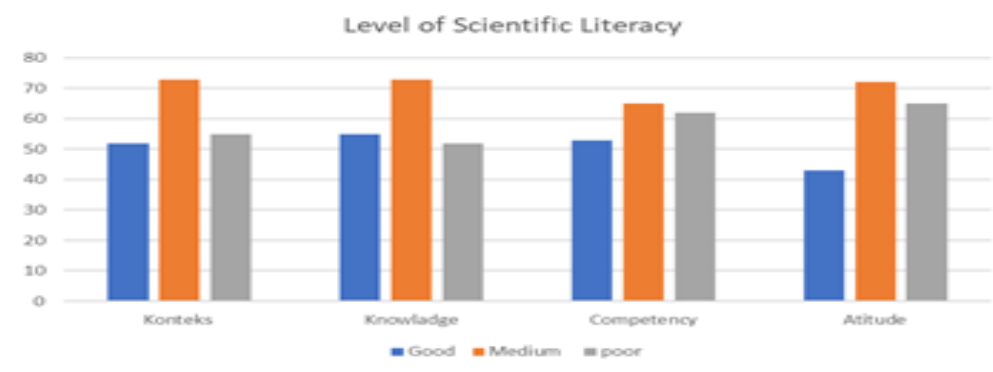

Fig. 3. Level of scientific literacy 
Mastery of science literacy skills is influenced by several factors, including the science learning model applied by the teacher in building knowledge concepts. A learning climate that is able to arouse students' curiosity and scientific attitudes regarding learning topics and encourages students to solve problems presented by the teacher is believed to be able to build a scientific process which is part of the aspect of scientific literacy competencies. One of the learning models suitable for science learning is the discovery model which uses the steps of the scientific method in building knowledge concepts. Science literacy skills also include the ability to understand Nature of Science which is in line with the concept of science inquiry skills such as designing experiments, collecting and analyzing data, and drawing conclusions drawn based on scientific evidence.

One of the science learning activities that encourage students to be able to construct their own knowledge is by applying learning methods based on discovery activities based on students' natural intelligence. Through these activities carried out in science learning, students can be able to plan their learning, carry out learning, and evaluate their learning independently. Scientific attitude is an activity which includes observation, finding problems, investigating books and other sources, planning investigations, conducting experiments, collecting data, analyzing data and interpreting, proposing solutions, explaining and presenting the results of investigations (National Research Council in Tatar, 2011). So, students' scientific literacy skills in the aspects of knowledge and scientific competences can be optimized through the application of discoverybased learning.

\section{Conclusion}

Based on the results of the research that has been done, it is concluded that the majority of teachers support the development of learning models to improve students' scientific literacy. The initial survey of the average scientific literacy abilities in the aspects of context, knowledge, competence and attitudes with the "good" achievement category. However, it is necessary to develop an innovative and effective learning model to further improve students' scientific literacy from good to very good categories.

\section{Acknowledgement}

Conceptualization (AS, KH); Research materials preparation (DS); Methodology (AS); Data collecting (AS, KH); Data analysis and visualization (AS, DM. T); Writing-original draft (AS); Presentation (AS).

\section{References}

[1] [1] T. Armstrong, Intelligences multiple in the classroom, vol. 18, no. 8. 2009.

[2] T. Armstrong, Setiap Anak Cerdas: Panduan Membantu Anak Belajar dengan Memanfaatkan Multiple Intelligence-nya. Jakarta: Gramedia, 2002.

[3] A. W. Wisudawati, “Metodologi Pembelajaran IPA,” Jakarta: Bumi Aksara, 2014. 
[4] P. Purnawarman, S. Ratnaningsih, and M. H. Gunawan, "Scientific Approach of 2013 Curriculum: Teachers Implementation in English Language Teaching,” English Rev. J. English Educ., vol. 6, no. 1, p. 33, 2017.

[5] S. Abdullah Ridwan, Pembelajaran Saintifik untuk Implementasi Kurikulum 2013. Jakarta: PT. Bumi Aksara, 2014.

[6] A. R. Uus Toharudin, Sri Hendrawati, Membangun literasi Sains peserta Didik. Bandung: Humaniora, 2011.

[7] P. Solving and F. Literacy, PISA 2012 Assessment and Analytical Framework PISA 2012 Assessment and Analytical Framework. 2012.

[8] Ari Suryawan, “Analisis pemahaman guru sd dalam mengimplementasikan scientific approach pada kurikulum 2013 di kabupaten magelang 1)," Holistika, vol. 4, no. 1, pp. 14-21, 2020. 